\title{
MODELLING THE STIRRING PROCESS OF BIOGAS PLANTS USING MIXED MATERIALS
}

\author{
Author(s): \\ Z. Bártfai - L. Tóth - I. Oldal - I. Szabó - J. Beke - N. Schrempf
}

\section{Affiliation:}

Szent István University, Faculty of Mechanical Engineering, 1.Páter K. street. Gödöllő, H2100

\section{Email address:}

bartfai.zoltan@gek.szie.hu, toth.laszo@gek.szie.hu, oldal.istvan@gek.szie.hu, szabo.istvan@gek.szie.hu, beke.janos@gek.szie.hu, schrempf.norbert@gek.szie.hu

\begin{abstract}
Among the possible energetic usages of biomass, producing biogas is the most compatible with the environment, while also ecologically correct. Fermentation technology to create biogas is mainly defined by the secondary and tertiary (leftovers and waste) biomass variants to be processed. The aftercare of such substances is required almost unilaterally, since there are environmental causes to be taken into consideration (f.e. diseases, damages to groundwater, etc.). During the process of biogas fermentation, the various substances become acceptable for environmental standards. Once the process is completed, useful heat and electric energy is produced, while fermented leftovers don't negatively impact the environment, furthermore, are in some cases, have soil enriching and reinvigorating effects.
\end{abstract}

\section{Keywords}

biogas, substrate stirring, modelling stirring method.

\section{Introduction}

Our research analysed a biogas plant, which has definitive differences between the variations of materials used and their relation to each other. Usually, we use primary biomass, and (secondary) waste variants from husbandry in agriculture $[1,2]$. These plants operate adequately, if proper material supply is assured, since the composition of materials is static. Technology used to process excess slurry is a different group among purification establishments, where the composition of the material can be similarly standardised.

The share of slurry in the substrate of our researched object may reach up to $55-65 \%$. Since said slurry comes from the sewage of 8-10 settlements, both the quantities and compositions of imported materials are very different. Also due to the $10-15 \%$ share of varied profile / composition foodstuff wastes, the substrate requires re-balancing.

The facility, producing $\sim 2,0 \mathrm{MWp}$ electric power is operated by a modern system. Figure 1 shows the system's structure.

The SDM container is responsible for preparing - mixing and grinding - bovine manure, which also has straw in it, and corn silage. This is where it's put into the pre-digester $(\mathrm{FF})$. The primary mixing of thin manure, sully and other fluids happens in the pre-container (WM) which can be heated as well. Various foodstuffs past their expiration dates, and other waste (kitchen waste, fatty materials from cleaning, depleted oil, fats from fat collectors, etc.) go into the grinder (WM). At this place, grinding and selection of various foodstuff wrappings (W) also happens, while thin materials are lead into the autoclave, kept at $70^{\circ} \mathrm{C}$ at least, for sterilising purposes.

GO biogas plants always aim to produce constant electric and heat energy production, which can be calculated as early as possible, which requires constant, undisturbed gas production [3]. There exists a prior report commitment for the static quantity (for the next 24 hours) of electric energy to be transferred (scheduling), and differences are sanctioned by the Hungarian energy system, and if said difference is over $20 \%$, a $15-18 \%$ fine in the purchase price is given [4].

These plants have to deal with various operation factors impeding gas yield, which was a result of foam in the digesters. Our goal was to increase gas yield, and get rid of the impeding factors.

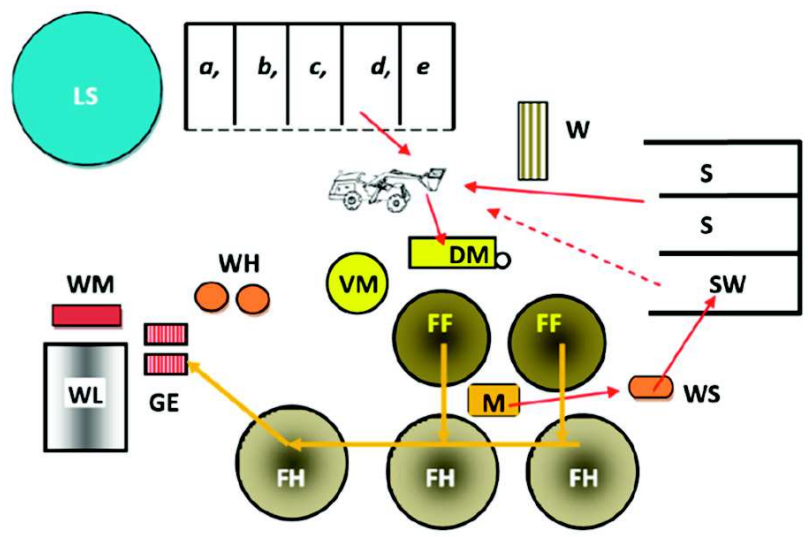

Figure 1. Arrangement of various facilities

$\mathrm{W}=$ Evaluation of inbound materials, $\mathrm{a}, \mathrm{b}, \mathrm{c}, \mathrm{d}=$ Temporary containers for various materials, $\mathrm{S}=$ Silage container $\mathrm{SW}=$ Separated terminal product container, $\mathrm{LS}=$ Terminal containment of thin material (lagoons), $\mathrm{VM}=$ Pre-container and mixer for fluids, $\mathrm{DM}=$ Mixing, grinding and containment of dry materials, $\mathrm{WH}=$ Sanitizer, $\mathrm{W}=$ Waste container,

$\mathrm{GE}=$ Gas-propelled blocks FF, FF $=$ Pre-digesters, FH, FH,

$\mathrm{FH}=$ Post-digesters, $\mathrm{M}=$ Suction-pump station, $\mathrm{WS}=$ Separator 
Generally, systems using similar mixed materials and slurry have an amount of $10-15 \%$. In our case, from an agricultural soil management, but also an energy gain perspective, using (putting in) $40-60 \%$ (non-contaminated) substance is quite descriptive [5].

In Hungary, up to 500.000 tons of slurry is generated annually, $58-65 \%$ of which goes to agriculture, $20-22 \%$ to waste dumps (depositories), $1-2 \%$ to combustion, and the remaining portion is more-or-less unknown. In 2015, 390.000 tons of slurry go to agriculture (dry materials / year, 65\%). Using biogas produced by fermenting slurry, a conservation of energy can be achieved, which decreases the costs of wastewater purification. By placing the fermented slurry in the agriculture, ecologic state of soil can be improved, since minerals and trace elements needed by plant life can be used for that purpose. This is why processing sewage slurry in fermentation systems important [6]. It's obvious that getting to know, and fixing the processes and problems of fermentation improves efficiency, and soil nutrition management in agriculture acquires an important resource (147/2010. (IV. 29.) Gov. enactment.).

\section{Overview of literature}

The following environmental factors have an impact on methane production: substrate concentration, adaptation of bacteria, $\mathrm{pH}$ value, ammonia concentration, and temperature [7].

The negative impact on gas yield - which also means efficiency - is caused by both biological and technological errors, f.e. the frothing of the reactors.

If the composition of the substrate injected into the digester changes, the composition of the micro-biologic population follows suit [8]. The numbers of some micro-organisms increase and their biological activity also hastens, while other microorganisms go through the exact opposite change. These changes may happen together with the changes in chemical and enzymatic properties of the micro-biologic population, which results in the new micro-biological population's ability to decompose the new substrate. This adaptation is not short-term, but happens over a longer timeframe, dependent on the reproduction speed of the population. If bacteria are put into a different environment, a certain amount of time passes before they adapt to the new circumstances, which is almost always longer than their generational timeframe. During the new period, bacteria adapt to the new environment (via changes in metabolism), after which they begin to reproduce again [9].

\section{Possible reasons of errors that might come up}

Kougias et al. [10] state that these problems - similarly, frothing as well - happened in the 16 facilities they analysed, to different degrees. The timeframe was usually 1-21 days, during which a gay yield loss of $20-50 \%$ was documented.

According to analyses in the Lemwig (Denmark) biogas plant, the main reason of decreased gas yield and frothing was both the composition of the substrate used and improper mixing attributes $[11,12]$.

Their measurements state that the bacteria colony didn't have an effect on frothing, by which they pointed out the indifference of the filamentosus (unlike other authors) in their co-substratebased reactor. However, they also stated that other bacteria (Gordonia, Microthrix, Parvicella) can result in errors of operation with sewage slurry fermentation. Multiple authors state that the feeding overload of the reactor, and the over-production of acetyl causes f.e. intensive frothing [13], where they worked with a $10 \%$ slurry load in the substrate at best. Load was gradually increased (for about 30 days), but due to avoiding frothing, slurry was re-circulated during the putting the system in operation, and $\mathrm{pH}$ values were stabilised using liming.
According to McCarthy [14], slurry as a substrate has all the nutrients required for bacteria, if $60-75 \%$ of the dry material component is organic. Oláh et. al. state that putting incoming organic waste into the digesters without any prior examination has dangers, since the unknown composition may end up in overload. This overload is shown via the strong frothing and the methane content of the gas produced suffering a serious decrease, merely 30 minutes after the fact.

What sources think the reasons of reduced gas yield and frothing are, and what their solutions might be:

-If the composition and specific quantity of used organic nutrition mix is close to static, there are almost no notable problems - this results in a balanced micro-biological population (at most, for $4 \mathrm{~kg} /$ day / $\mathrm{m} 3$ reactor volume) [15].

- The $\mathrm{C} / \mathrm{N}$ ratio is important, since to build proteins, nitrogen is required. If there's not enough nitrogen, the amount of carbon processed decreases, and if there's too much, there will be too much ammonia, which inhibits methane generation. A C / N value of 15-30 litres is optimal, which can be set via properly mixing the base materials [15].

- The optimal $\mathrm{pH}$ value of bacteria causing hydrolysis or fermentation is 4,5-6,3, and 7-7,5 for methanogens (a value below 6,8 in digesters might be a bad impact) [13].

-By mixing the material properly, we can improve effectiveness, and the efficiency of fermentation [16].

-If there's an erratic temperature change in the substrate, methane production decreases, and this common temperature difference breaks biochemical equilibrium [9].

- The optimal environment for mesophile bacteria is at $35-40^{\circ} \mathrm{C}$. This temperature has to be kept stable in the entire reactor.

- The most important factor is the dry component ratio, which defines the system's load. Quantity and concentration both define the proper input data.

- Organic volatile acid content has to be monitored at all times, just like $\mathrm{HCO} 3$ content and its ammonium ion concentration. Keeping the volatile acid content below $1000 \mathrm{mg}$ of acetyl / 1 average is optimal [15].

- The FOS / TAK value is usually optimal at $0,3-0,4 \mathrm{~kg}$ in the reactor (however, it can only be defined via frequent systemspecific, longer duration measurements). The value is between $0,2-0,3$ in the post-digester and the lagoons. A FOS / TAK value below 0,2 signifies that not enough organic material is present, however, if it goes above 0,4 , there's too much organic material [17].

By checking the presented data [18], and incorporating them, the system can be stabilised, but will worsen, if the system requires mandatory changes due to mechanical errors, or transport times of materials are delayed, mixing - after input, or in-between - isn't done, etc.

\section{Source and method}

\section{Requirements of input}

The technology took using various materials into consideration, the composition of which may differ during transport. Variations used continually and always:

-Silo corn,

-Bovine manure,

-Thin manure,

-Sewage slurry* (from 12 sources, in different compositions).

Less frequent materials:

-Foodstuff leftovers, *

-Oil- and fat slurry,* 
-Foodstuffs over expiration date (meat, chips, ice cream, etc.), *

-Depleted oil, and oil past expiration date.

* Note: quite different, with unknown composition when arriving.

To keep efficiency as good as possible, the manager can set the composition in the pre-mixer using the data he got from composition estimations before input, while the reactor substrate's temperature and composition spread can only be influenced with the inner mixers. As for the latter, it has to be taken into consideration during planning, meaning the system's specs define f.e. the level of grinding, the equality in composition spread for the entire inner area, and the same for temperature homogeny $[19$, 20].

We can create "recipes" for input, meaning we can almost completely optimise the composition ( $\mathrm{CN}$ ratio, $\mathrm{pH}$ value, FOS / TAK, etc.) [21].

\section{Attributes of sewage slurry types}

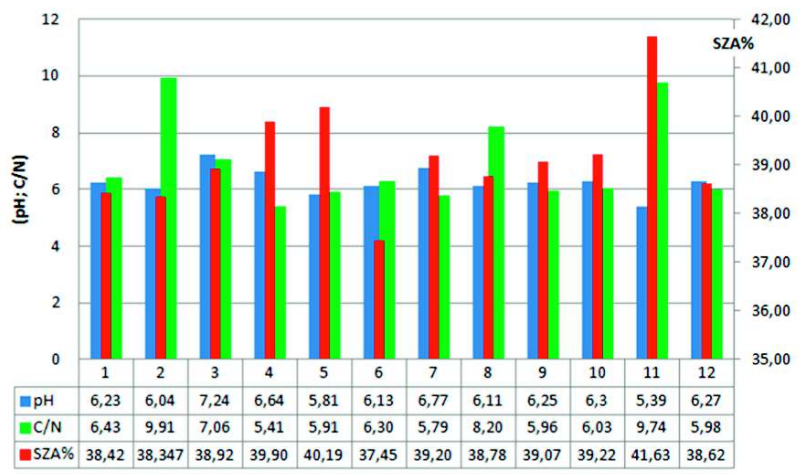

Figure 2. Dry material content, $\mathrm{pH}$ value and $\mathrm{C} / \mathrm{N}$ ratio of the 12 sewage slurry samples (avg. values)

The samples arriving from 12 different places were analysed, some of the more important results are shown in Illustration 3. The dry material volume in some samples are quite different, but the carbon amount for dry material is roughly the same [22, 23]. The biggest problem is that some samples have quite the different $\mathrm{pH}$ values, and the $\mathrm{C} / \mathrm{N}$ ratio is also quite varied, which have to be equalised by other materials, which however generates other imbalances to equalise in turn (Figure 2). There was a substantial difference in energy volume of some samples. A higher energy content means in a lower ash content, which showed some samples held a high amount of minerals, probably due to the mechanical errors in the water purifier's sand partitioning systems.

Heavy (granular) minerals cause an efficiency decrease in stirring, increase energy requirement, and lead to the wearing of blades due to their quick decanting. Manure which contains straw also has a high concentration of sand, which doesn't only cause blades to wear, but does the same to the percussion hammers of the grinding machine, and due to their wearing, the grinding effect decreases almost to zero, thereby resulting in long straws (cellulose) entering the reactor, where they stick to the blades, reducing their stirring effect, or even causes the blades to break in some cases [24].

The efficiency of stirring was evaluated with samples from before and after said stirring happened (temperature, $\mathrm{pH}$ value, amount of organic material), but we didn't see any big differences, which is why we ran a check on the stirring system, its arrangement, and level of activity.

\section{Stirring system}

Requirements of proper management [25, 26, 27, 28, 29]:

A Adding thicker or thinner material has to allow setting the density for the entire mass.

B A static $\mathrm{pH}$ value and temperature level has to be possible for the entire volume (making heat extractable from the heating bodies, and evenly distributable).

C Micro-organisms have to be in a forced connection with the nutrients.

D The entire volume is effective, there aren't any so-called dead spaces. Material components which inhibit the process have to be thinned.

E The decanting of the substrate isn't allowed, which homogenises nutrition content.

F.Materials which change position relative to each other leave the bacteria, enter the gas material, and cause bubbles to appear via their so-called velocity shear.

\section{Stirring possibilities [3]}

- Via mechanical method (various bladed mixers),

- Via recirculation of the entire substrate and fluid phase, including the slurry (fluid beam made via pumps),

-Via gas bellowing (layer swap),

Biogas plants use various mechanical mixers. There are two common variations shown on Illustration 3 .

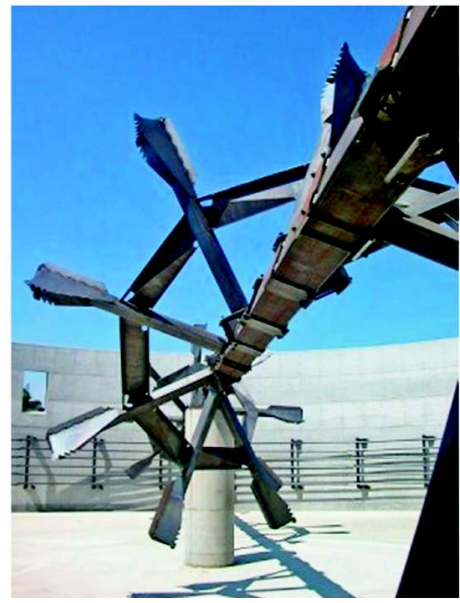

A

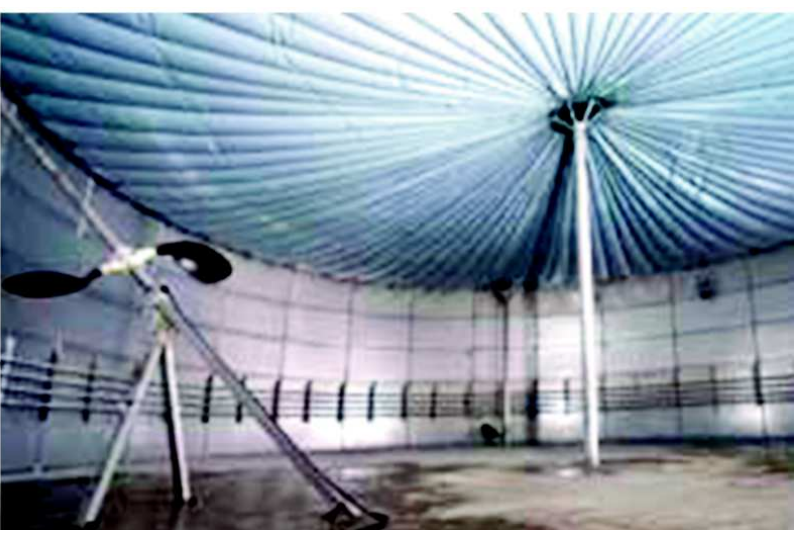

B

Figure 3. A - horizontal axis, spiral bladed mixer, B - slanted axis propeller mixer

\section{Solution at the analysis' site}

There are four mixers found in the pre-digesters, and three in the post-digesters at the complex we analysed. The stirring process 
is more important at the pre-digesters, meaning analysing and modelling was done for that one. As for the pre-digesters, there's 1800-2000 tonnes of material in case of an $80 \%$ load, to which adding 14-20 tonnes of extra material doesn't cause a substantial increase in temperature $(0,6-0,8 \mathrm{oC})$ in either spring or autumn, but not even in summer. Even for the non-extraordinary winter season, the difference isn't that much, if the heating system operates properly $(1,0-2,0 \mathrm{oC})$. In case of a lower outside temperature, even $6-8 \mathrm{oC}$ isn't that unusual after input.

The cross-section of the pre-digester, and the three variable and one fixed mixers can be seen on Figure 4, 5 and 6.

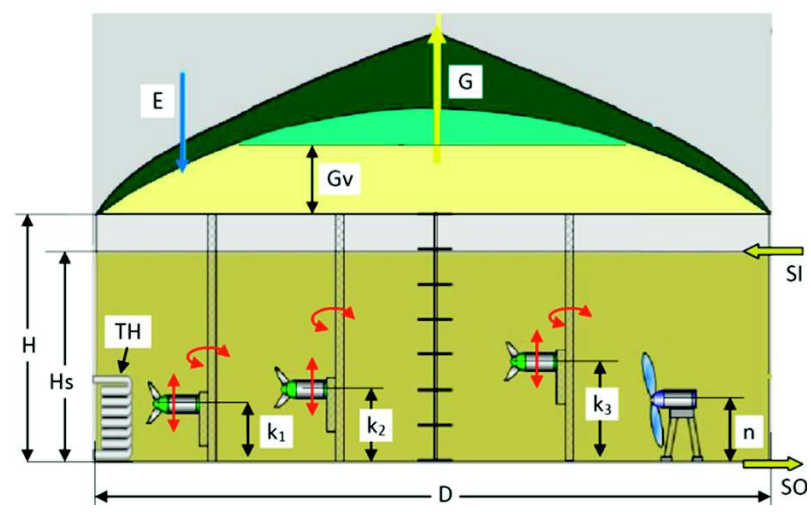

Figure 4. Mixers of the digesters

Abbreviations: $\mathrm{D}$-diameter of the reactor, $\mathrm{H}$ - height of the reactor wall, $\mathrm{Hs}-$ height of suspension in the reactor, $\mathrm{TH}-$ tube heating on the walls, E - entry of air, area of removing sulphur, $\mathrm{G}$ - gas drain, Gv - gas volume and its changes, SI - substrate input, $\mathrm{SO}$ - substrate output, $\mathrm{k}_{1}, \mathrm{k}_{2}, \mathrm{k}_{3}$ - mixers with variable height and angle, $\mathrm{n}$ - fixed big mixer.
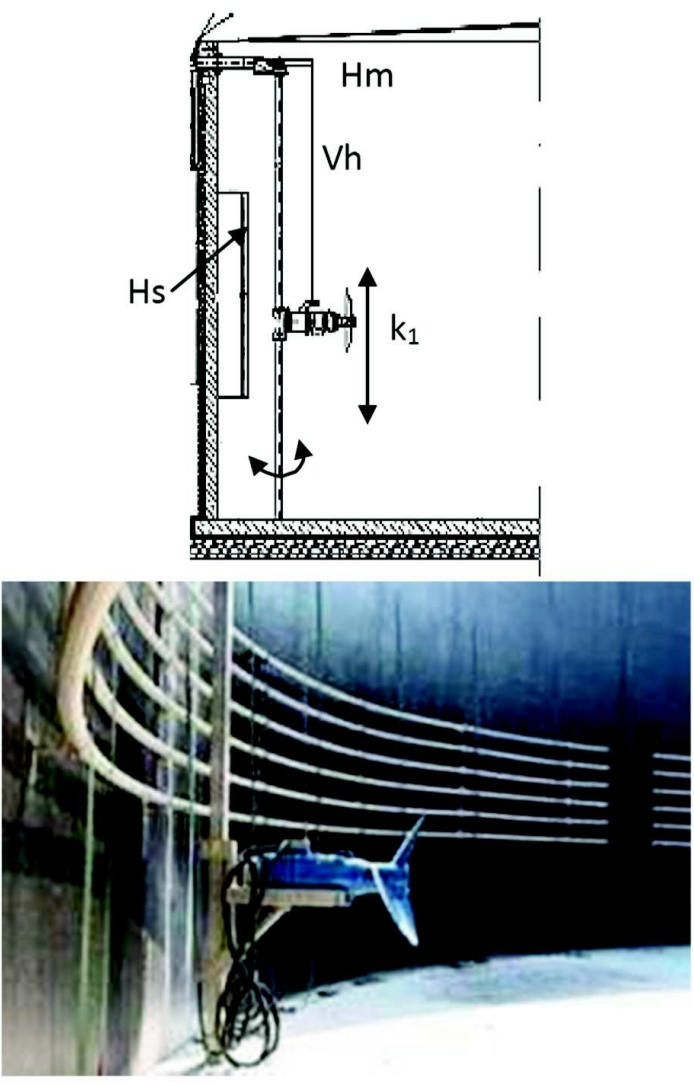

Figure 5. Small mixers $\left(\mathrm{k}_{1}\right)$ and installation scheme $\mathrm{Vh}$ - vertical setting, $\mathrm{Hm}$ - horizontal setting, Hs - heating tubes

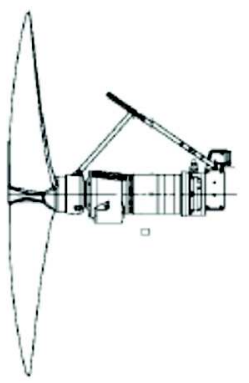

no

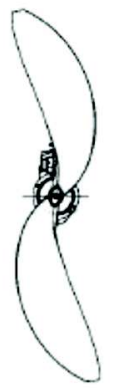

nh

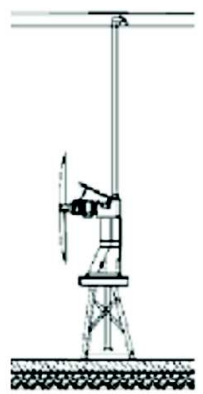

n
Figure 6. Large-diameter fixed mixer no - large mixer (side view), nh - large mixer (front view), $\mathrm{n}$ - large mixer installation schematic

How substrates react to stirring

The substrates in the reactor can be considered viscous fluids if they contain $10-14 \%$ of organic matter. In the case of viscous fluids' flow, fluid parts which have a difference in velocity cause shear stress (Figure 7). In case of continuously parallel flow fluid layers, there's an inner friction force $(\mathrm{F})$ contradictory to the direction of movement, which is directly proportional to the area sizes (A) causing the friction (moving on each other), and the velocity gradient $(\mathrm{du} / \mathrm{dy})$. The ratio factor is none other than the static describing the material quality of the fluid, in other words, the dynamic viscosity $(\eta=\operatorname{Pa~} s)$ :

$$
\eta=\frac{A}{F} \frac{d u}{d y}
$$

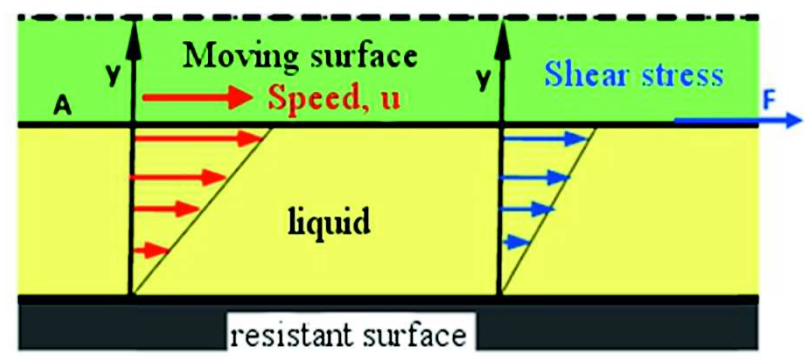

Figure 7. Description of the shear stress

( $\mathrm{u}$ - velocity, $\mathrm{y}$ - fluid thickness)

Using the F/A physical quantity, we can write shear stress using the law $\tau,\left[\mathrm{N} / \mathrm{m}^{2}\right]$ :

$$
\tau=-\eta \frac{d u}{d y}
$$

Where the velocity gradient, or velocity shear $\left[\mathrm{s}^{-1}\right]$ is as follows:

$$
\dot{\gamma}=\frac{d u}{d y}
$$

Newton's viscosity law states that the shear stress between various layers is directly proportional to the velocity gradient. This isn't directly proportional in case of non-newtonian fluids, meaning there's a more complex formula between shear stress and velocity gradient.

Dynamic viscosity $(\eta)$ can be defined as the quotient of shear stress and velocity shear $\left[\mathrm{kg} \mathrm{m}^{-1} \mathrm{~s}^{-1}\right.$, or Pa s]:

$$
\eta=-\frac{\tau}{\dot{\gamma}}
$$


Therefore, shear stress in the fluids depends on the shear gradient. This function is directly proportional for Newton's and Bigham's fluids, but non-newtonian fluids give a convex or concave function, in other words, different to linear change.

Materials which have about $10 \%$ dry material content used by biogas fermentation aren't Newton's fluids, and are rather pseudoplastic in nature. Maier et al. [29] analysed a substrate, for which velocity shear was reduced by an increase in viscosity. The shear factor exists due to the interaction between the fluid, and the hard molecules in the material. Molecules often break the continuity of the flow, which impact the mixing of various elements. Björn et. al. [30] state that the reactor substrates' dry material content, dynamic viscosity and their related factors offer no easy to state relation, while rheological attributes are important for the efficiency of mixing. Getting to know these relations is important when designing mixing systems. In the case of sewage slurry variants, raising the dry material content also increases the limit of dynamic viscosity, the rate of which depends on the size of granules in the material, to be precise, their increase causes a decrease in said statistics. Sinking due to granule size has an effect on velocity shear, and the rate of material stirring.

Homogeny is dependent not only on the attributes of the fluid, but also the configuration of the tank, and the attributes of mixer performance [21]

When viscosity increases, the velocity shear gradient usually follows suit. In the case of lighter material parts, a greater decrease in viscosity is required, compared to more heavy ones, to breate the same velocity gradient. However, the behaviour of the sediment and the slurry showed differences (Figure 8).

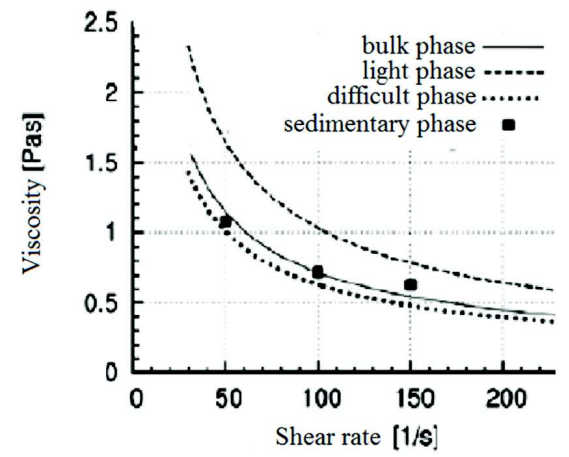

Figure 8. Relations between viscosity and velocity shear [4]

Shear performance is related to performance put into stirring, which means the values of velocity shear are greatly dependent on the attributes of the mixing machinery (drive performance, peripheral speed, shape attributes).

As for a different analysis, in case of given materials and also taking various consistencies into consideration, running the simulation on relations resemble Figure 9.

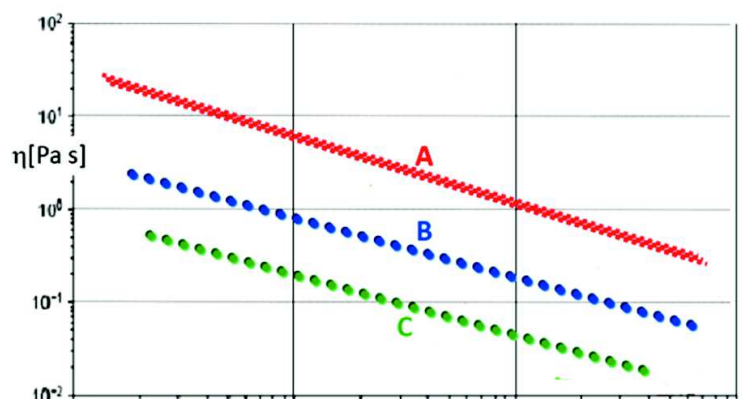

Figure 9. Rheological attributes of the substrate according to measurements of designated materials by the Oswal-de Waele relation (logarithmic scale) [25] Materials being: A- corn silage, B - sewage slurry, C - organic waste
According to the processed sources, we can state that materials in the biogas digesters can be defined by three phases: light (ascending), heavy (sinking), and floating (colloid and smaller) granules. The proper homogeny of these three attributes inside the internal volume - taking the whole mass into consideration can only be maintained via stirring.

To reach a favourable gas yield, there are huge differences in both the number of times stirring is required, and the timeframe of stirring for the various reactor types and mixer solutions (according to authors researching the topic). The general practice is to stir 3-6 times a day, 0,5-3 hours each.

\section{Model analyses}

In the system we selected to model, by rotating the 3 small mixers (k), we see the activation area by moving it to the maximum value (R), and the theoretic motion volume by moving the conical beam (RSn). Similarly, there's a static fluid beam in the case of the big mixer (n) (Figure 10).

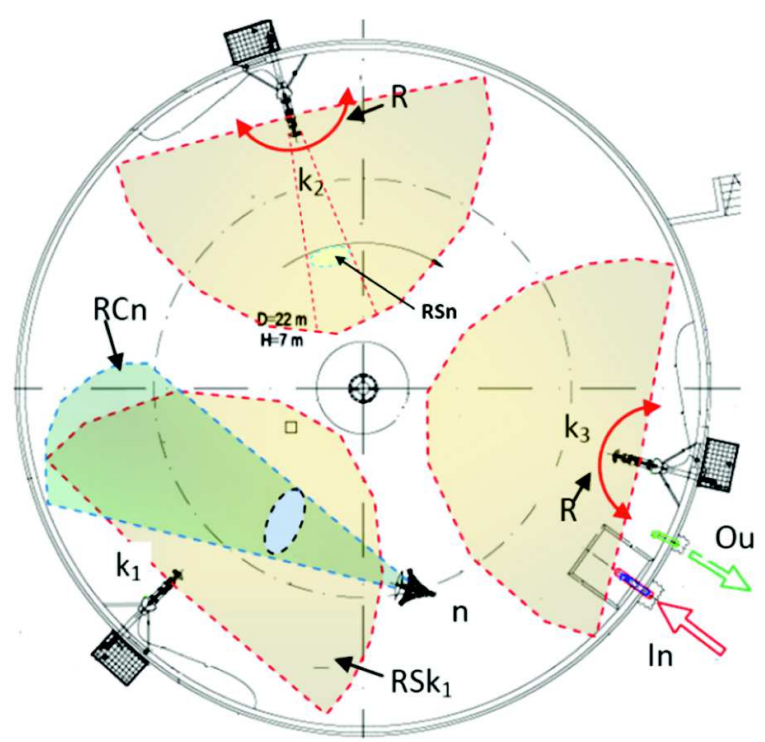

Figure 10. Arrangement of mixers, and effect areas in the predigester $\mathrm{k} 1, \mathrm{k} 2, \mathrm{k} 3$ - variable height and angle mixers, $\mathrm{n}$ - fixed big mixer, $\mathrm{R}-$ level and direction of rotation, $\mathrm{In} / \mathrm{Ou}$ - input and output of substrate, RSk - area of effect for small mixers (only as an indication), $\mathrm{RCn}$ - conical area of effect of the big

mixer, RSn - conical area of effect of the small mixers

We chose the CFD method to model, while taking the framework conditions obtained by the measurements, and possible solution methods into considerations [14]. The viscosity of the "mixture" in the biogas reactor, which has a $10-12 \%$ dry material content is $300-1000$ fold compared to that of water at $20^{\circ} \mathrm{C}, 1,0020 \mathrm{cP}$, which means it's $300-1000 \mathrm{cP}$, meaning $0,3-1,0$ $\mathrm{Pa}$.

Of course, realistic circumstances differ greatly, since the material isn't homogenous, it contains both bits and pieces, and fibrous parts.

In our first approach, we did the calculations with water, to get the flow directions and movement data of water molecules at various mixer positions without any disturbance. This means the models didn't designate velocity values as important, but instead focused on the movement of the matter molecules compared to each other in space. Figure 11 shows possible main positions.

According to the illustration:

- mixers $\mathrm{k}_{1}$. $\mathrm{k}_{2}$ és $\mathrm{k}_{3}$ were defined by 9 basic positions each $(3$ height $-\mathrm{v}_{1}-\mathrm{v}_{3}-$ and 3 heights each $-\mathrm{h}_{1}-\mathrm{h}_{3}$ ). 
-Each could take either position not related to each other, but altogether, all triad positions have to be different. This makes the number of possible configurations $9 \times 8 \times 7=504$.

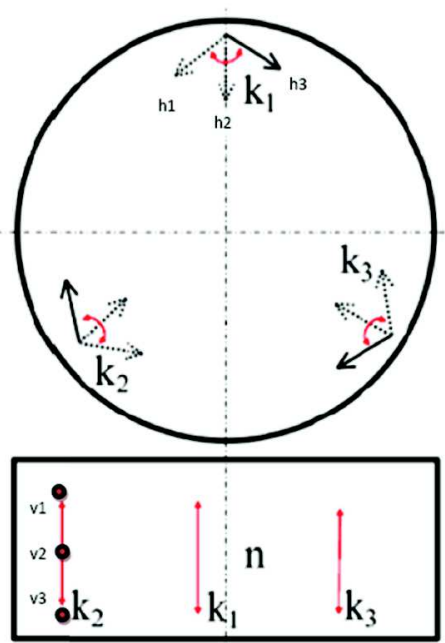

Figure 11. Small (k) and large (n) mixers (the position of which can't be changed, it's installed in a static manner)

If we chose different positions to the designated ones, the number of possible combinations is "infinite", which is why we analysed the ones most specific to stirring, by giving border values. The results were checked for the suspension forecast, and an extra $10 \%$ dry material content as well. After running the program, we analysed 192 variations (for the given viscosity, water, and higher density). The positions presented in our document can be seen on Figure 12.
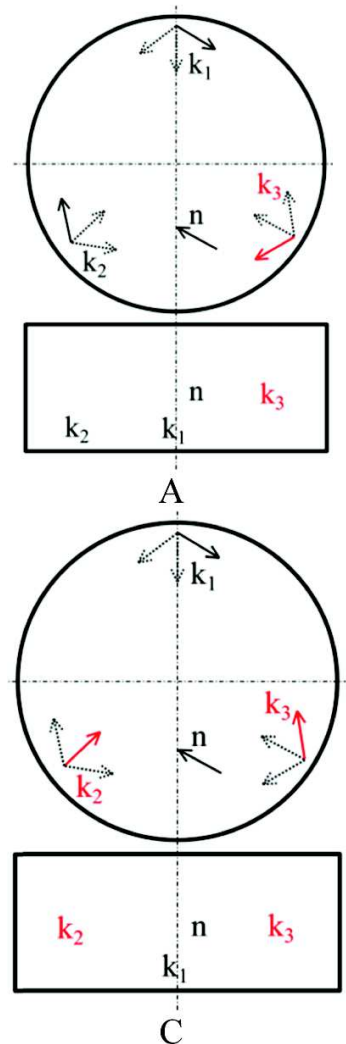

Figure 12. Blade positions selected for showing the model ("with border values")

A All $(\mathrm{k})$ mixers stirring in the same direction, one in middle height.

B One (k) mixer down, two in mid-height, one stirring radially.
C One (k) mixer down, two in mid-height, but different directions, one stirring radially.

D All three in different heights, but stirring in the same direction.

Velocities in the direction of the flow are presented on Figure $13,14,15,16$
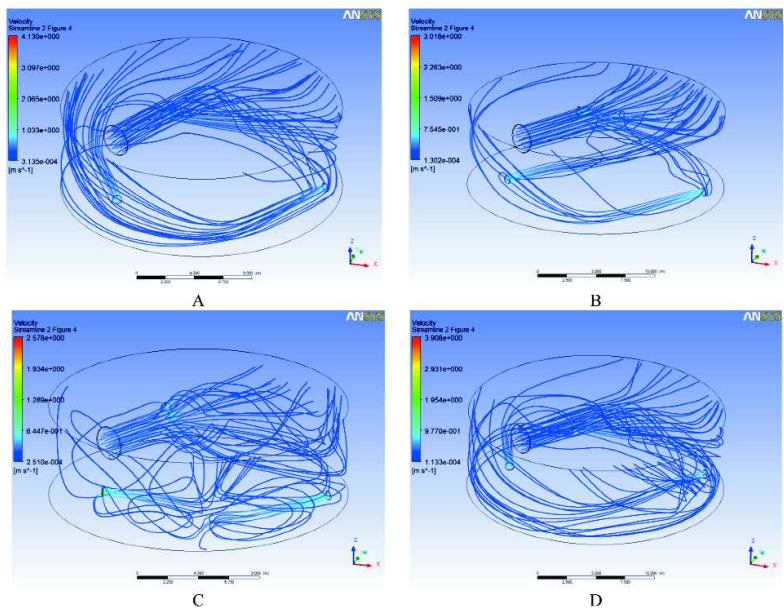

Figure 13. Velocity starting from the mixers, in the direction of the flow Highest value is for A $(1-2 \mathrm{~m} / \mathrm{s})$, lowest for C $(\sim 0,0$ $\mathrm{m} / \mathrm{s})$

The velocity lines of the big mixer extend to the wall facing it, and generate an upward draft after crashing into it. The small mixers generating the other flow are concentrated near the wall if the transport is in a single direction, and only turn towards the surface in case of a crash. Facing flows are impossible to calculate, and becomes chaotic. Radial guidance helps the flow upward, but isn't beneficial for heat exchange, since their flows don't reach the wall.

Flow on the upper and lower levels of the fluid

After analysing these layers, variations $\mathrm{A}$ and $\mathrm{D}$ are more beneficial, since there's a balanced, and sufficient flow circling around the wall, meaning heat exchange for heating is beneficial. However, inside the planes, intensity is higher, and areas almost static are less in number. Variation $\mathrm{C}$ isn't recommended, since movements satisfy almost no requirement at all.

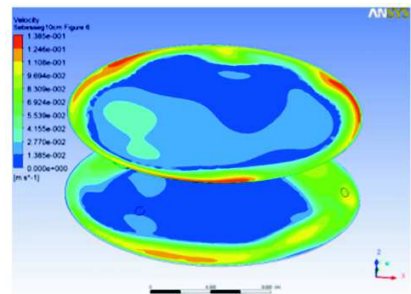

A

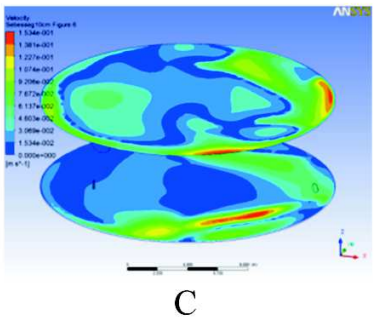

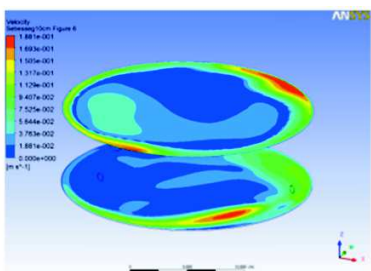

B

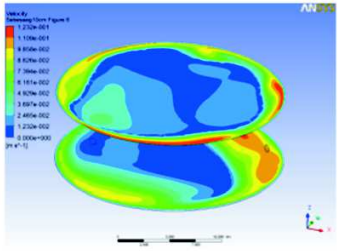

D
Figure 14. Motion deciphered in an area for the $0,1 \mathrm{~m}$ surface and lower level plane of the material inside the reactor Highest velocity: $1,8 \mathrm{~m} / \mathrm{s}$ Lowest velocity: $\sim 0,0 \mathrm{~m} / \mathrm{s}$ 
Our notes for the upper and lower planes are supported by the section in the middle area as well. The consistent flow near the walls is the most important here, since the heating pipe system is also at this height (see Figure 5 above).
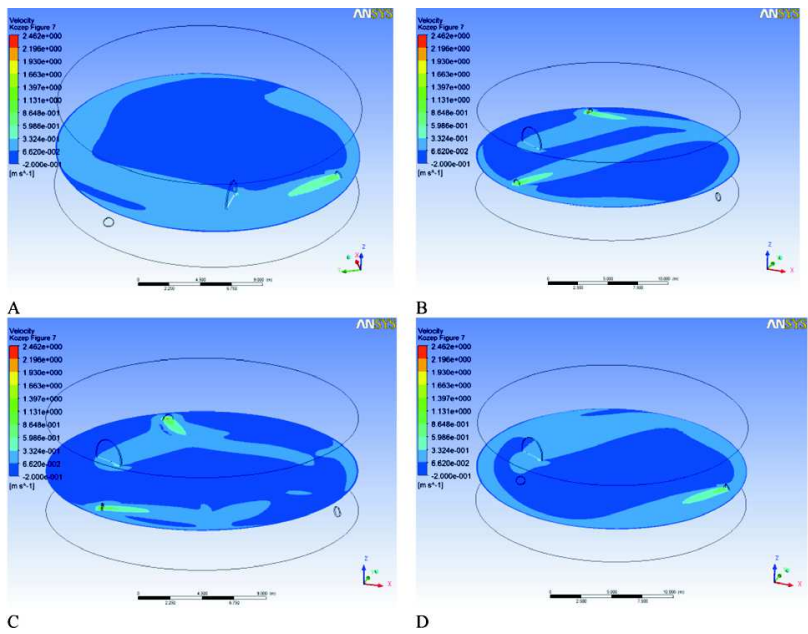

Figure 15. Motion deciphered in the horizontal middle plane of the material inside the reactor

Highest velocity: on the blade's deformed side $\sim 2,1-2,6 \mathrm{~m} / \mathrm{s}$, and 2-3 meters away from the blades (directly after the blade, it reaches up to $4,0 \mathrm{~m} / \mathrm{s}$ ). Lowest velocity in the flow is $\sim 0,12 \mathrm{~m} / \mathrm{s}$.

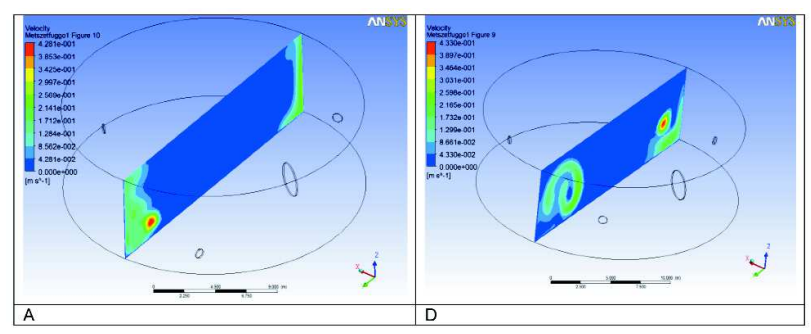

Figure 16. Motion deciphered in the vertical middle plane of the material inside the reactor

Variation A shows the most beneficial movement on vertical sections, which shows that there's intensive movement near the heat exchanging walls. This has an importance in the winter season, when outside temperature is low, and the material put in follows suit, and a need for intensive heating, and heat exchanging arises. Variation D shows an intensive vertical whirlpool, which extends to the wall at variations $\mathrm{C}$ and $\mathrm{B}$ more, while at A, less. The highest velocity can be observed on the blade's deformed side - $\sim 2,1-2,6 \mathrm{~m} / \mathrm{s}$ - which remains even $2-3 \mathrm{~m}$ away from the blades. The lowest velocity is $\sim 0,2 \mathrm{~m} / \mathrm{s}$.

\section{Results}

Main conclusions:

- The total amount of material in the digesters can't be put into motion consistently in the current system. Theoretically, there's no need to do so, since heat exchange near the heat expending surfaces can only be done with a stronger material flow.

-Due to incorrect stirring directions set in the system, masses not in motion can also develop meaning there's a need to validate beneficial variations suggested by the modelling, via inserting thermometers.

- The timeframe of stirring cycles, their number and intensity can only be validated by measuring gas yield.
-It seems to be obvious that after the material input, a more intensive stirring period is required, which can be realised by raising the rotational speed of the mixers, or in other words, improving the transport mass-flow. Keeping the higher intensity isn't required, since life support of the methanogene bacteria is reduced by a higher velocity shear between matter molecules. More intensive stirring also helps in creating thermal homogeny of the material mass, and shortening the time needed for general homogeny. To reach this effect, it's important to supply the mixers with rotation frequency adjusters, which makes it possible to get close to optimal material movements.

- Time required for stirring increases, and requires more energy consumption, if the substrate contains much more dense granulates. In the case of sewage slurry, transportation companies should check the proper operation of sand partitioning systems.

- The optimum of time spent between stirring tasks can only be set via evaluating gas yield.

\section{First actual plant results to validate calculations and modelling}

While doing experiments for 5 months, we were trying to - as much as we were able to - reach the best mix for input, and match stirring to the model. This was often problematic to do professionally, due to mechanical errors, constipations, and the fact that some materials weren't present when they were required. As for the latter, we can learn that there should be capacity to stock up, which can help avoid errors due to lack of materials, meaning we should make materials always ready to use.

The amounts $\left(\mathrm{m}^{3}\right)$ of materials put in from the 3 main points of input were shown on Figure 9. The pre-container serves to provide mainly thin manure, sewage slurry, and materials used to thin taken from the lagoons. The mass input changes, since separation also happens, and equalising the separated mass' volume happens from the pre-container. The quantity of this volume is a fundamentally defining factor for the system. The silo and straw manure is put in from the dry grinder, and sometimes, the quantity of fermented and separated dry material (in smaller quantity) can be kept constant. The Higi (AC) area offers input for various foodstuff waste in sterilised form, and the materials contained in the fat container (their percentage isn't that high though).

As a result of model-like implementation, the gas yield for nutrients put in was improved. Electric and heat energies were taken into consideration in a $40 / 60 \%$ ratio (Figure 17). During almost 3 months, the volume of energy increased from $61,2 \%$ to $68,7 \%$ (Table 1). This proves that our thoughts were correct. By improving the stirring, efficiency will probably improve even further.

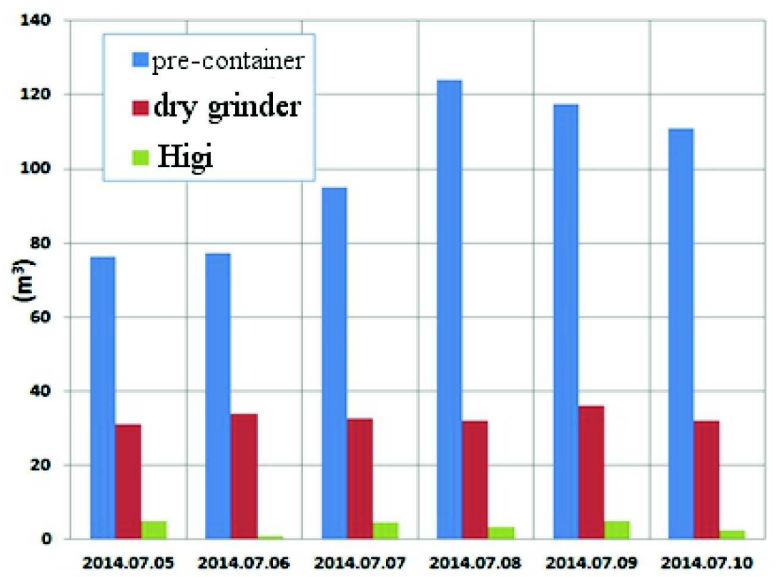

Figure 17. Current load on the system regarding electric energy 
Table 1. The Volume of Energy

\begin{tabular}{|c|c|c|}
\hline $\begin{array}{c}\text { Intemal performance of } \\
\text { the generator } \mathrm{P}_{\mathrm{m}} \\
{[\mathrm{MWh} / \text { month }]}\end{array}$ & $\begin{array}{c}\text { Energy denved from } \\
\text { nutrients } * * \\
{\left[\mathrm{P}_{\mathrm{t} 2}\right][\mathrm{MWh} / \text { month] }}\end{array}$ & $\begin{array}{l}\text { Energy denved from } \\
\text { nutrients } * \boldsymbol{\Phi} \\
{\left[\mathrm{P}_{\mathrm{t} 1}\right][\mathrm{MWh} / \mathrm{month}]}\end{array}$ \\
\hline 1480,560 & $1.017,60$ & 916,20 \\
\hline 0 & $\left(P_{*} \cdot B_{m}\right) 1000$ & $\left(\mathrm{~B} \cdot \mathrm{P}_{\mathrm{m}}\right) 1000$ \\
\hline $100 \% 0$ & $68,7 \% 0$ & $61,2 \% 0$ \\
\hline
\end{tabular}

Notes: $\quad *$ input farther from the recipe

** input closer to the recipe

\section{Conclusion}

Our article showcased how one element of a biogas plant works. These plants will be more and more typical as we see them, since it's both a government aim, and the European Union also supports biogas plants linked to sewage water purifiers. The plant can be built right on the purifier's grounds (using mixed materials), but it's beneficial to build it in the vicinity of multiple purifiers, which are similar to the one we introduced in our article. Usually, the biggest management problem is the varied physical nature of incoming materials, and the differences in content of various transported goods. Operations without problems can only work if so-called "input recipes" are made for the materials, which are selected by the most important parameters (shown in our research). Consequent input and stirring (homogenising) improves the gas yield by nutrients on average $(\mathrm{m} 3 / \mathrm{kg})$. Hungary produces up to 500.000 tonnes of sewage slurry, only $20 \%$ of which is delivered to a biogas facility for fermentation (most of it is poured into deponies), while anaerobic fermentation is the most optimal, and ecologically beneficial solution, since energetic end products (electricity, heat) are not the only benefits - another example would be bio-manure useful for soil management.

Acknowledgements

This work was supported by: TÁMOP 4.2.2.D-15/1/Konv2015-0011 számú "Interdiszciplináris nemzetközi kutatói teamek létrehozása Békés megyében" (Creating inter-disciplinary international research teams in Békés county)

\section{References}

[1.] Bayerische Landesanstalt für Landwirtschaft (LfL).: 2006. Biogastechnologie zur umweltverträglichen Flüssigmistverwertung und Energiegewinnung in Wasserschutzgebieten

[2.] Tóth L., Fogarassy Cs.: 2012. Low-carbonenergiaellátási rendszerek a gyakorlatban. A megújuló energiatermeléstechnológiái Magyarországon. Szaktudás Kiadó Ház Zrt., Budapest, 2012 ISBN:978-615-5224-37-9 p. 112-156

[3.] Berglund M., Börjesson P.: 2006. Assessment of energy performance in the life-cycle of biogas production, Elsevier, Biomass and Bioenergy Volume 30, Issue 3, March 2006, pp 254 266. http://dx.doi.org/doi:10.1016/j.biombioe.2005.11.011

[4.] Tóth L. -Beke J - Sembery P. - Hajdú J.: 2012. The role of biomass in Hungarian energy supply, Hungarian Agricultural Research, Journal of the Ministry of Rural Development Hungary, Vol. 21, Nr. 4. ISSN 1216 4826. 14-19 p.

[5.] Domahidy L. Gy.: 2013 A szennyvíziszapra vonatkozó hazai szabályozás tervezett változtatásai Budapest

[6.] Kovács et all.: 2003. A szennyvíziszap-kezelés és hasznosítás jogi, gazdasági, müszaki, környezetegészségügyi feltételrendszere.

[7.] Oláh J., Palkó Gy., Szilágyi M., Barabás Gy., Gyarmati I., Tuba L.: 2010 Rothasztók üzemeltetése, Magyar Szennyvíztechnikai Szövetség

[8.] Gerardi, M. H. 2003. The Microbiology of Anaerobic Digesters, John Wiley \& Sons, Inc., Publication, $11-57$
[9.] Gruber, W. 2007. Biogasanlagen in der Landwirtschaft. Aid infodienst Verbraucherschultz, Ernährung, Landwirtschaft e.V. Bonn.

1453.

[10.] Kougias P. G., Boe K., Thong S. O, Kristensen L. A. and Angelidaki I.: 2014. Anaerobic digestion foaming in full-scale biogas plants: a survey on causes and solutions, ISWA publishing [11.] Loum A., Fogarassy Cs.: 2015. The effects of climate change on cereals yield of production and food security in Gambia. Applied Studies in Agribusiness and Commerce APSTRACT Vol. 9. No. 4. pp. 83-92. http://dx.doi.org/10.19041/APSTRACT/2015/4/11

[12.] Borocz M., Horvath B., Herczeg B., Kovacs A.: 2015. Greener cement sector and potential climate strategy development between 2015-2030 (Hungarian case study). Applied Studies in Agribusiness and Commerce - APSTRACT Vol. 9. No. 4. pp. $65-74$.

http://dx.doi.org/10.19041/APSTRACT/2015/4/9

[13.] Boe K. et al.: 2008 Serial CSTR digester configuration for improving biogas production from manure. Water Research Volume 43, Issue 1, January 2009, Pages 166-172 [14.] McCarthy K., Murphy J. D.: 2005. The optimal production of biogas for use as a transport fuel in Ireland Renewable Energy, Elsevier Volume 30, Issue 14, November 2005, Pages 2111-2127. http://dx.doi.org/doi:10.1016/j.renene.2005.02.004

[15.] Zehnsdorf A., L. Moeller , K. Görsch, V. Beer. Bernburg.: 2010. Schaumbildung in Biogasanlagen, Hemholtz, Zentrum für Umweltforschung UFZ, 30. November [16.] Shen Fei; Tian, Libin; Yuan, Hairong; Pang, Yunzhi; Chen, Shulin; Zou, Dexun; Zhu, Baoning; Liu, Yanping; Li, Xiujin.: 2013. Improving the Mixing Performances of Rice Straw Anaerobic Digestion for Higher Biogas Production by Computational Fluid Dynamics (CFD) Simulation, Applied Biochemistry \& Biotechnology; Academic Journal. EBSCO Publishing is a division of United

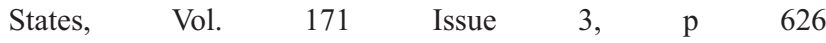
http://dx.doi.org/doi:10.1007/s12010-013-0375-z

[17.] Tóth L., Beke J., Bártfai Z., Szabó I., Hartdégen G., Oldal I., Blahunka Z.: 2014. Technological Features of Biogas Plants Using Mixed Materials, HUNGARIAN AGRICULTURAL ENGINEERING, $\quad N^{\circ}$ 26/2014 39-46, Published online: HU ISSN 0864-7410 (Print) / HU ISSN 2415-9751(online)

http://dx.doi.org/doi:10.17676/hae.2014.26.39.

[18.] Esteves S., Miltner M., Fletch S.: 2013. Folyamatos ellenőrzési útmutató a biogáz és biometán üzemek megfelelö müködtetéséhez, Intelligent Energy Europe [19.] Banks C. J., Chesshire M., Heaven S., Arnold R.: 2011. Anaerobic digestion of source-segregated domestic food waste: Performance assessment by mass and energy balance Bioresource Technology, Volume 102, Issue 2, January 2011, pp.612-620. http://dx.doi.org/10.1016/j.biortech.2010.08.005

[20.] Fantozzi F., Buratti C.: 2011 Biogas production from different substrates in an experimental Continuously Stirred Tank Reactor anaerobic digester.

[21.] Seyssiecq I., Ferasse J. H., Roche N.: 2003. State-of-theart the rheological characterization of waste water treatment sludge. Biochemical Engineering Journal, Vol.16, pp. 41-56. http://dx.doi.org/doi:10.1016/s1369-703x(03)00021-4

[22.] Fogarassy Cs., Horvath B., Kovacs A.: 2015. Cross-sector analysis of the Hungarian sectors covered by the Effort Sharing Decision - Climate policy perspectives for the Hungarian agriculture within the 2021-2030 EU programming period. Applied Studies in Agribusiness and Commerce - APSTRACT Vol. 9. No. 4.4 pp. 17-24. http://dx.doi.org/10.19041/APSTRACT/2015/4/2 
[23.] Fogarassy Cs., Horvath B., Szoke L., Kovacs A.: 2015. Low-carbon innovation policy with the use of biorenewables in the transport sector until 2030. Applied Studies in Agribusiness and Commerce - APSTRACT Vol. 9. No. 4. pp. 45-52. http://dx.doi.org/10.19041/APSTRACT/2015/4/6

[24.] Wu B.: 2013. Advances in the use of CFD to characterize, design and optimize bioenergy systems. Computers and Electronics in Agriculture 93(0), 195-208.

http://dx.doi.org/doi:10.1016/j.compag.2012.05.008

[25.] Brehmera M., Kraumea M.: 2012. Mixing Performances In Biogas Plants, Technische Universität Berlin, 14th European Conference on Mixing, Warszawa, 10-13 September.

[26.] Kaparaju P., Buendia I., Ellegaard L., Angelidakia I.: 2008. Effects of mixing on methane production during thermophilic anaerobic digestion of manure: Lab-scale and pilotscale studies, Bioresource Technology Volume 99, Issue 11, pp. 4919-4928. http://dx.doi.org/doi:10.1016/j.biortech.2007.09.015 [27.] Kardos L.: 2012. A szennyvíztelepi biogáz termel fermentációs folyamatok nyomonkövetése kémiai és biokémiai módszerekkel Eötvös Loránd Tudományegyetem, Természettudományi Kar, Bp. Környezettudományi Doktori Iskola pp. 113114.

[28.] Lindmark, J., Thorin, E., Bel Fdhila, R., Dahlquist, E.: 2014. Effects of mixing on the result of anaerobic digestion: Review. Renewable and Sustainable Energy Reviews 40(0), 1030-1047. http://dx.doi.org/doi:10.1016/j.rser.2014.07.182

[29.] Maier C., Weichselbaum W., Schlerka M., Harasek M.: 2010 Development of Agitation Systems in Biogas Plants: Investigation of Mixing Characteristics, Improvement of Energy Efficiency and Scale-up using CFD Getreidemarkt 9/166-2, 1060 Vienna, Austria www.aidic.it/cet/10/21/200.

[30.] Björn A., Segura de La Monja P., Karlsson A., Ejlertsson J., Bo J., Svensson H. B.: 2012. Rheological Characterization, Biogas, ISBN: 978-953-51-0204-5, InTech,

http://dx.doi.org/doi:10.5772/32596 